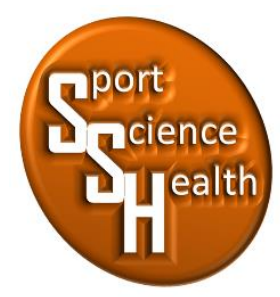

ISSN 2715-3886

\title{
Studi Tentang Indeks Massa Tubuh Terhadap Kondisi Fisik Atlet Muaythai Pusat Pelatihan Kabupaten Malang
}

\author{
Ja'far Baihaqi ${ }^{1 *}$, Eko Hariyanto ${ }^{2}$ \\ 1,2Jurusan Pendidikan Jasmani, Kesehatan dan Rekreasi, Fakultas IImu Keolahragaan, \\ Universitas Negeri Malang, Jalan Semarang No 5, Malang, Jawa Timur, 65145, Indonesia \\ *Penulis koresponden: haqi2331@gmail.com, 085735649015
}

Artikel diterima: 2 Januari 2020; direvisi: 12 Oktober 2020; disetujui: 22 Oktober 2020

\begin{abstract}
The research describes the study of body mass index on the physical condition of muaythai athletes in Malang Regency. Using descriptive quantitative correlational method. The research subjects were 9 athletes. Results: 1) BMl of boys and girls was classified as normal with an average of $66.67 \%$. 2) The relationship of BMI to abdominal muscle strength for men (0.218) is less than $(0.811)$ and girls $(-0.987)$ less than (0.997). 3) The relationship of BMI to male (0.395) arm muscle strength is less than $(0.811)$ and female $(-0.277)$ less than $(0.997)$. 4) The relationship between $\mathrm{BMI}$ and the explosive power of boys (0.836) was more than $(0.811)$ and girls $(0.999)$ were more than (0.997). The relationship of BMI to male speed $(0.363)$ is less than $(0.811)$ and girls $(0.438)$ less than (0.997). 5) The relationship of BMI to male endurance $(0.234)$ is less than $(0.811)$ female $(0.327)$ less than (0.997). Conclusion: There is only a relationship between BMI and explosive power, there is no relationship between $\mathrm{BMI}$ on abdominal muscle strength, arm muscle, speed and endurance.
\end{abstract}

Keyword: body mass index, physical condition, muaythai athletes

\begin{abstract}
Abstrak: Penelitian menejelaskan studi tentang indeks massa tubuh terhadap kondisi fisik atlet muaythai Kabupaten Malang. Mengunakan deskriptif kuantitatif metode korelasional. Subjek penelitian 9 atlet. Hasil:1) IMT putra, putri tergolong normal rata-rata $66,67 \%$. 2) Hubungan IMT terhadap kekuatan otot perut putra $(0,218)$ kurang dari $(0,811)$ dan putri $(-0,987)$ kurang dari $(0,997)$. 3)Hubungan IMT terhadap kekuatan otot lengan putra $(0,395)$ kurang dari $(0,811)$ dan putri $(-0,277)$ kurang dari $(0,997)$. 4)Hubungan IMT terhadap daya ledak putra $(0,836)$ lebih dari $(0,811)$ dan putri $(0,999)$ lebih dari $(0,997)$. Hubungan IMT terhadap kecepatan putra $(0,363)$ kurang dari $(0,811)$ dan putri $(0,438)$ kurang dari $(0,997)$. 5) Hubungan IMT terhadap daya tahan putra $(0,234)$ kurang dari $(0,811)$ putri $(0,327)$ kurang dari $(0,997)$. Simpulan: Hanya ada hubungan antara IMT terhadap daya ledak, tidak ada hubungan antara IMT terhadap kekuatan otot perut, otot lengan, kecepatan dan daya tahan.
\end{abstract}

Kata kunci: indeks massa tubuh, kondisi fisik, atlet muaythai 


\section{PENDAHULUAN}

Salah satu aspek yang sangat penting dalam dunia olahraga khusunya cabang olahraga beladiri adalah indeks massa tubuh dan kondisi fisik. Namun kenyataannya banyak atlet yang kurang memperhatikan asupan makanan atau gizi yang dikonsumsi. Berdasarkan penelitian Setiawan (2014) menunjukan bahwa kondisi fisik Atlet Tarung Derajat Kota Kediri sebagian besar berada pada kategori cukup sebanyak 6 atlet dengan presentase sebesar $67 \%$ kategori kurang sebanyak 0 atlet dengan presentase sebesar $0 \%$ kategori sangat kurang 1 atlet dengan presentase sebesar $11 \%$ kategori sangat baik sebanyak 0 atlet dengan presentase $0 \%$ dan kategori baik 2 atlet dengan presentase sebesar 22\%. Prihatini dan Achmad menyatakan ada hubungan yang signifikan antara indek massa tubuh dengan daya tahan kardiovaskuler dan kelincahan pemain sepakbola yang mana hubungan dinyatakan kuat namun dengan korelasi hubungan yang berbeda dengan penjelasan dari hubungan indeks massa tubuh dan daya tahan kardiovaskuler (Prihatini \& Achmad, 2019). Melalui pengamatan yang sudah dilakukan oleh peneliti, atlet muaythai Kabupaten Malang termasuk dalam ketegori baik. Hal ini berpengaruh terhadap program latihan yang diberikan oleh pelatih yang mana akan berpengaruh terhadap kondisi fisik. Walaupun ada beberapa faktor yang mempengaruhi kondisi fisik salah satunya adalah gizi. Muaythai adalah olahraga pertempuran brutal dan atletis, dengan teknik yang memanfaatkan tinju, siku, lutut, dan kaki sebagai senjata yang dominan dengan lawan.

Indeks massa tubuh adalah menilai kategori tubuh dengan menggunakan perbandingan antara IMT/U atau BB/PB dengan median menurut umur, berat badan, panjang badan. Pengukuran ini mempunyai kelebihan yaitu dapat mengetahui gambaran resiko kegemukan anak (Yuliana \& Winarno, 2020)

Kondisi fisik merupakan kebutuhan yang paling dasar dalam olahraga, kondisi merupakan unsur yang sangat penting hampir diseluruh cabang olahraga membutuhkan fisik yang prima karena kondisi fisik yang baik akan menunjang kemampuan taktik dan teknik atlet saat melakukan pertandingan (Ariffiansyah, 2019). Kondisi fisik atlet muaythai bisa diukur dengan melihat pengukuran indeks massa tubuh dan suksesnya program latihan yang diberikan oleh pelatih.

\section{Indeks Massa Tubuh (IMT)}

Koup Devenport menggunakan cara penilaian status gizi dengan menghitung Indeks massa tubuh atau Body Mass Index (BMI). Cara yang digunakan untuk mengetahui status gizi orang dewasa berusia 18 tahun atau lebih. Indeks Massa Tubuh memiliki kelebihan, yaitu: 1) Pengukuran sederhana dan mudah dilakukan. 2) Dapat menentukan kelebihan dan kekurangan berat badan. Berdasarkan pendapat di atas dapat disimpulkan bahwa indeks massa tubuh adalah salah satu cara untuk mengukur antara berat badan dengan tinggi badan dengan tujuan untuk mengetahui kategori status gizi dari seseorang atau atlet (Bohlen, Boll, Schwarzer, \& Groneberg, 2015; Haro et al., 2016; Labocha, Schutz, \& Hayes, 2014; Locke et al., 2015; Nuttall, 2015; Queensland Goverment, 2013).

\section{Kondisi Fisik}

Kondisi fisik adalah keadaan kemampuan jasmani yang dapat menyesuaikan fungsi alat-alat tubuhnya terhadap tugas jasmani. Kondisi fisik yang baik akan menunjang kemampuan taktik dan teknik atlet saat latihan maupun pertandingan (Griwijoyo, 2013:21). Sedangkan menurut Pakar, Kondisi fisik adalah suatu kualitas fisik, kualitas psikis dan kemampuan fungsional peralatan tubuh individu. Kondisi fisik juga merupakan suatu hal penting untuk olahraga prestasi karena kondisi fisik sangat menentukan kualitas dan kemampuan untuk tuntutan pretasi yang optimal (Diputra, 2015).

\section{Muaythai}

Muaythai adalah olahraga pertempuran brutal dan atletis, dengan peserta memanfaatkan tinju, siku, lutut, dan kaki sebagai senjata yang dominan dengan lawan. Muaythai dipraktekkan secara luas di Thailand, dengan partisipasi internasional secara signifikan berkembang selama dekade terakhir (C. Chinnasee et al., 2018; Chamnan Chinnasee et al., 2018; Diniz et al., 2018; Montoya, 2019; Orhan, Yücel, Sadeq, \& Orhan, 2019; Phosawat Saengsawang, Chairit Siladech, \& Prapat Laxanaphisuth, 2015).

\section{Kekuatan}

Kekuatan adalah kemampuan otot atau sekelompok otot untuk melakukan satu kali kontraksi secara maksimal melawan tahanan atau beban. Kekuatan otot sangat penting bagi setiap orang ataupun atlet. Kekuatan otot ini untuk memperkuat atlet dalam melakukan gerak pada olahraga apapun seperti sepakbola (Suchomel, 
Nimphius, Bellon, \& Stone, 2018; Suchomel, Nimphius, \& Stone, 2016). Kekuatan adalah kemampuan otot untuk melakukan kontraksi guna membangkitkan tegangan terhadap suatu tahanan (Hartmann et al., 2015; Suchomel et al., 2018, 2016).

\section{Kelincahan}

Kelincahan adalah kemampuan mengubah arah atau posisi tubuh dengan cepat yang dilakukan bersamasama dengan gerakan lainnya. Kelincahan dibutuhkan untuk gerakan-gerakan yang cepat dan juga tetap seimbang atau tidak jatuh dari tumpuan (Samsudin \& Rahman, 2016). Kelincahan adalah kemampuan seseorang untuk dapat mengubah arah dengan cepat dan tepat pada waktu bergerak tanpa kehilangan keseimbangan (Arifin \& Warni, 2019).

\section{Kecepatan}

kecepatan adalah kemampuan berpindah dari satu tempat ke tempat yang lain dalam waktu yang sesingkatsingkatnya. Kecepatan bersifat lokomotor dan gerakannya bersifat siklik (satu jenis gerak yang dilakukan berulang-ulang seperti lari dan sebagainya) atau kecepatan gerak bagian tubuh seperti melakukan pukulan. Dalam hal ini kecepatan sangat penting untuk tetap menjaga mobilitas bagi setiap orang atau atlet (Haugen, Tønnessen, Hisdal, \& Seiler, 2014; Horicka, Hianik, \& Šimonek, 2014).

\section{Daya Ledak}

Daya ledak adalah gabungan antara kecepatan dan kekuatan atau pengarahan gaya otot maksimum dengan kecepatan maksimum. kemampuan yang cepat dan kuat juga dibutuhkan atlet untuk melakukan gerakangerakan yang cepat dan perlu tenaga kuat (Rahmansyah, Jufrianis, \& Tangkudung, 2018; Sunardi, Sujiono, \& Marani, 2019).

\section{Daya tahan}

Daya tahan jantung dan paru-paru adalah kesanggupan sistem jantung, paru-paru dan pembuluh darah untuk berfungsi secara optimal saat melakukan aktivitas sehari-hari, dalam waktu cukup lama tanpa mengalami kelelahan yang berarti. Daya tahan ini juga sangat penting untuk menunjang kerja otot dengan mengambil oksigen dan mengeluarkan ke otot yang aktif. Daya tahan yang kuat juga akan menjaga permainan atlet agar tetap dalam kondisi fisik yang baik (Mach \& Fuster-Botella, 2017; Volek, Noakes, \& Phinney, 2015).

Berdasarkan paparan data di atas terdapat kesamaan atau sejalan antara teori dan fakta yang ditemukan di lapangan dan hasil wawancara yang dilakukan penulis kepada pelatih muaythai Kabupayen Malang, oleh karena itu indeks massa tubuh dan kondisi fisik atlet muaythai Kabupaten Malang perlu dikaji lebih lanjut dengan demikian penulis akan melakukan penelitian yang berjudul "Studi Tentang Indeks Massa Tubuh Terhadap Kondisi Fisik Atlet Muaythai Pusat Pelatihan Kabupaten Malang.

\section{METODE}

Penelitian ini menggunakan pendekatan deskriptif kuantitatif dengan menggunakan metode korelasional dengan variabel bebas: indeks massa tubuh $(X)$ dan variabel terikat tingkat kebugaran jasmani $(Y)$, dan subjek penelitian 9 atlet terdiri dari 6 atlet putra dan 3 atlet putri. Penelitian ini bertempatkan di Desa Kidangbang Kecamatan Wajak Kabupaten Malang, waktu penelitian ini pada minggu terakhir pada bulan Oktober 2019. Instrumen pada penelitian ini adalah tes dan pengukuran indeks massa tubuh, sedangkan analisis data menggunakan presentase dan product Moment dari Person. Sedangkan penelitian yang digunakan adalah studi, yang bertujuan untuk mendapatkan informasi dan mendeskripsikan tentang hubungan indeks massa tubuh terhadap kondisi fisik atlet muaythai Kabupaten Malang.

\section{HASIL}

Tabel 1. Hasil Pengukuran IMT putra

\begin{tabular}{ccccc}
\hline No & Katgoeri & Nilai IMT $(\mathrm{Pa})$ & Frekuensi $(\mathrm{Pa})$ & $\begin{array}{c}\text { Presentase }(\mathrm{Pa}) \\
(\%)\end{array}$ \\
\hline 1 & Kurus & $<20,1$ & 1 & $16,67 \%$ \\
2 & Normal & $20,1-25,0$ & 4 & $66,67 \%$ \\
\hline
\end{tabular}




\begin{tabular}{ccccc}
\hline 3 & Obesitas & $>30$ & 0 & $0 \%$ \\
4 & Rata-rata & 22,0 & 1 & $16.67 \%$ \\
Jumlah & & 6 & $100 \%$ \\
\hline
\end{tabular}

Tabel 2. Hasil Pengukuran IMT putri

\begin{tabular}{ccccc}
\hline No & Katgoeri & Nilai IMT $(\mathrm{Pi})$ & Frekuensi $(\mathrm{Pi})$ & Presentase $(\mathrm{Pi})(\%)$ \\
\hline 1 & Kurus & $<18,7$ & 0 & $0 \%$ \\
2 & Normal & $18,7-23,8$ & 2 & $66,67 \%$ \\
3 & Obesitas & $>28,6$ & 0 & $0 \%$ \\
4 & Rata-rata & 20,8 & 1 & $33,33 \%$ \\
Jumlah & & 3 & $100 \%$ \\
\hline
\end{tabular}

Tabel 3. Hasil Tes Sit Up Atlet Muaythai (Putra)

\begin{tabular}{lllll}
\hline No & $\begin{array}{l}\text { Kelas Interval } \\
(/ 60 \text { detik) }\end{array}$ & Kategori & Frekuensi & Persentase (\%) \\
\hline 1 & $\geq 48$ & Sangat Baik & 1 & $17 \%$ \\
2 & $42-47$ & Baik & 0 & $0 \%$ \\
3 & $38-41$ & Cukup & 1 & $17 \%$ \\
4 & $33-37$ & Kurang & 3 & $50 \%$ \\
5 & $\leq 32$ & Sangat Kurang & 1 & $16 \%$ \\
\hline & Jumlah & & 6 & 100 \\
\hline
\end{tabular}

Tabel 4. Hasil Tes Sit Up Atlet Muaythai (Putri)

\begin{tabular}{lllll}
\hline No & $\begin{array}{l}\text { Kelas Interval } \\
(/ 60 \text { detik })\end{array}$ & Kategori & Frekuensi & Persentase (\%) \\
\hline 1 & $\geq 42$ & Sangat Baik & 0 & $0 \%$ \\
2 & $36-41$ & Baik & 0 & $0 \%$ \\
3 & $31-35$ & Cukup & 2 & $67 \%$ \\
4 & $27-30$ & Kurang & 1 & $33 \%$ \\
5 & $\leq 26$ & Sangat Kurang & 0 & $0 \%$ \\
\hline & & 3 & 100 \\
\hline
\end{tabular}

Tabel 5. Hasil Tes Push Up Atlet Muaythai (Putra)

\begin{tabular}{rllll}
\hline No & $\begin{array}{l}\text { Kelas Interval } \\
(/ 60 \text { detik) }\end{array}$ & Kategori & Frekuensi & Persentase (\%) \\
\hline 1 & $70-$ ke atas & Baik Sekali & 0 & $0 \%$ \\
2 & $54-69$ & Baik & 0 & $0 \%$ \\
3 & $38-58$ & Sedang & 2 & $33 \%$ \\
4 & $22-37$ & Kurang & 4 & $67 \%$ \\
5 & ke bawah -21 & Kurang Sekali & 0 & $0 \%$ \\
\cline { 2 - 5 } & Jumlah & 6 & 100 \\
\hline
\end{tabular}

Tabel 6. Hasil Tes Push Up Atlet Muaythai (Putri)

\begin{tabular}{cllll}
\hline No & $\begin{array}{l}\text { Kelas Interval } \\
(/ 60 \text { detik) }\end{array}$ & Kategori & Frekuensi & Persentase(\%) \\
\hline 1 & $70-$ ke atas & Baik Sekali & 0 & $0 \%$ \\
2 & $54-69$ & Baik & 0 & $0 \%$ \\
3 & $38-58$ & Sedang & 0 & $0 \%$ \\
4 & $22-37$ & Kurang & 3 & $100 \%$ \\
5 & ke bawah -21 & Kurang Sekali & 0 & $0 \%$ \\
\hline & Jumlah & & 3 & 100 \\
\hline
\end{tabular}


Tabel 7. Hasil Tes Standing Long Jump Atlet Muaythai Putra

\begin{tabular}{lllll}
\hline No & Kelas Interval & Kategori & Frekuensi & Persentase (\%) \\
\hline 1 & $>250$ & Baik Sekali & 1 & $16 \%$ \\
2 & $241-250$ & Baik & 0 & $0 \%$ \\
3 & $231-240$ & Cukup & 1 & $17 \%$ \\
4 & $221-230$ & Sedang & 1 & $17 \%$ \\
5 & $211-220$ & Kurang & 2 & $33 \%$ \\
6 & $191-210$ & Poor & 1 & $17 \%$ \\
7 & $<191$ & Very Poor & 0 & $0 \%$ \\
\hline & Jumlah & & 6 & 100 \\
\hline
\end{tabular}

Tabel 8. Hasil Tes Standing Long Jump Atlet Muaythai (Putri)

\begin{tabular}{lllll}
\hline No & Kelas Interval & Kategori & Frekuensi & Persentase (\%) \\
\hline 1 & $>200$ & Baik Sekali & 0 & $0 \%$ \\
2 & $191-200$ & Baik & 1 & $33 \%$ \\
3 & $181-190$ & Cukup & 0 & $0 \%$ \\
4 & $171-180$ & Sedang & 1 & $34 \%$ \\
5 & $161-170$ & Kurang & 1 & $33 \%$ \\
6 & $141-160$ & Poor & 0 & $0 \%$ \\
7 & $<141$ & Very Poor & 0 & $0 \%$ \\
\hline \multicolumn{2}{l}{ Jumlah } & & 3 & 100 \\
\hline
\end{tabular}

Tabel 9. Hasil Tes Hasil Tes Sprint 30 Meter Atlet Muaythai (Putra)

\begin{tabular}{lllll}
\hline No & Kelas Interval & Kategori & Frekuensi & Persentase (\%) \\
\hline 1 & $<4.0$ detik & Unggul & 2 & $33 \%$ \\
2 & $4,2-4,0$ detik & Di atas rata-rata & 2 & $33 \%$ \\
3 & $4,4-4,3$ detik & Rata-rata & 2 & $34 \%$ \\
4 & $4,6-4,5$ detik & Di bawah rata-rata & 0 & $0 \%$ \\
5 & $>4,6$ detik & Kurang & 0 & $0 \%$ \\
\hline & Jumlah & & 6 & 100 \\
\hline
\end{tabular}

Tabel 10. Hasil Tes Hasil Tes Sprint 30 Meter Atlet Muaythai (Putri)

\begin{tabular}{lllcl}
\hline No & Kelas Interval & Kategori & Frekuensi & Persentase $(\%)$ \\
\hline 1 & $<4,5$ detik & Unggul & 0 & $0 \%$ \\
2 & $4,6-4,5$ detik & Di atas rata-rata & 0 & $0 \%$ \\
3 & $4,8-4,7$ detik & Rata-rata & 0 & $0 \%$ \\
4 & $5,0-4,9$ detik & Di bawah rata-rata & 2 & $67 \%$ \\
5 & $>5.0$ detik & Kurang & 1 & $33 \%$ \\
\hline & & 3 & 100 \\
\hline
\end{tabular}


Tabel 11. Distribusi Data Vo2max Atlet Muaythai (Putra)

\begin{tabular}{cclll}
\hline No & Kelas Interval & \multicolumn{1}{c}{ Kategori } & Frekuensi & Persentase(\%) \\
\hline 1 & $<35,0$ & Jelek & 0 & $0 \%$ \\
2 & $35,0-39,9$ & Di bawah rata-rata & 0 & $0 \%$ \\
3 & $40,5-45,1$ & Rata-Rata & 4 & $67 \%$ \\
4 & $45,2-50,9$ & Di atas rata-rata & 0 & $0 \%$ \\
5 & $51,0-55,9$ & Baik & 2 & $33 \%$ \\
6 & $>55,9$ & Sangat Baik & 0 & $0 \%$ \\
\hline & & 6 & 100 \\
\hline
\end{tabular}

Tabel 12. Distribusi Data Vo2max Atlet Muaythai (Putri)

\begin{tabular}{cclll}
\hline No & Kelas Interval & Kategori & Frekuensi & Persentase(\%) \\
\hline 1 & $<33,0$ & Jelek & 0 & $0 \%$ \\
2 & $33,0-37,1$ & Di bawah rata-rata & 3 & 100 \\
3 & $37,8-42,4$ & Rata-Rata & 0 & $0 \%$ \\
4 & $43,3-46,8$ & Di atas rata-rata & 0 & $0 \%$ \\
5 & $47,4-52,5$ & Baik & 0 & $0 \%$ \\
6 & $>52,6$ & Sangat Baik & 0 & $0 \%$ \\
\hline & Jumlah & 3 & 100 \\
\hline
\end{tabular}

Tabel 13. Koefisien Korelasi antara Variabel Indeks Massa Tubuh (X) dan Kondisi Fisik (Y) Atlet Putra.

\begin{tabular}{|c|c|c|c|c|}
\hline & $\begin{array}{c}\text { Komponen } \\
\text { Kondisi Fisik }\end{array}$ & $\begin{array}{c}\text { Taraf } \\
\text { Signifikansi }\end{array}$ & $\begin{array}{c}\text { Hasil } \\
\text { Signifikansi }\end{array}$ & keterangan \\
\hline & Kekuatan Otot & & $0,218<0,811$ & Tidak \\
\hline Indek Massa & Perut & $r_{\text {hitung }}>r_{\text {tabel }}$ & & Signifikan \\
\hline \multirow[t]{4}{*}{ Tubuh } & $\begin{array}{l}\text { Kekuatan otot } \\
\text { lengan }\end{array}$ & $r_{\text {tabel }}=0,811$ & $0,395<0,811$ & $\begin{array}{l}\text { Tidak } \\
\text { Signifikan }\end{array}$ \\
\hline & Daya ledak & & $0,836>0,811$ & Signifikan \\
\hline & Kecepatan & & $0,363<0,811$ & $\begin{array}{l}\text { Tidak } \\
\text { signifikan }\end{array}$ \\
\hline & MFT & & $0,234<0,811$ & $\begin{array}{l}\text { Tidak } \\
\text { Signifikan }\end{array}$ \\
\hline
\end{tabular}

Tabel 14. Koefisien Korelasi antara Variabel Indeks Massa tubuh (X) dan Kondisi Fisik (Y) Atlet Putri.

\begin{tabular}{|c|c|c|c|c|}
\hline & $\begin{array}{l}\text { Komponen } \\
\text { Kondisi Fisik }\end{array}$ & $\begin{array}{c}\text { Taraf } \\
\text { Signifikansi }\end{array}$ & $\begin{array}{c}\text { Hasil } \\
\text { Signifikansi }\end{array}$ & keterangan \\
\hline Indek Massa & $\begin{array}{l}\text { Kekuatan otot } \\
\text { perut }\end{array}$ & $r_{\text {hitung }}>r_{\text {tabel }}$ & $-0,987<0,997$ & $\begin{array}{l}\text { Tidak } \\
\text { Signifikan }\end{array}$ \\
\hline \multirow[t]{4}{*}{ Tubuh } & $\begin{array}{l}\text { Kekuatan otot } \\
\text { lengan }\end{array}$ & $r_{\text {tabel }}=0,997$ & $-0,277<0,997$ & $\begin{array}{l}\text { Tidak } \\
\text { Signifikan }\end{array}$ \\
\hline & Daya Ledak & & $0,999>0,997$ & Signifikan \\
\hline & Kecepatan & & $0,438<0,997$ & $\begin{array}{l}\text { Tidak } \\
\text { signifikan }\end{array}$ \\
\hline & MFT & & $0,327<0,997$ & $\begin{array}{l}\text { Tidak } \\
\text { Signifikan }\end{array}$ \\
\hline
\end{tabular}

Kriteria penerimaan atau penolakan hipotesis pada koefisien korelasi dengan $\alpha=0,05$ adalah jika $R_{\text {hitung }}>$ $\mathrm{R}_{\text {tabel }}$ maka terdapat hubungan yang signifikan $\left(\mathrm{H}_{0}\right)$ ditolak dan $\left(\mathrm{H}_{\mathrm{a}}\right)$ diterima, jika $\leq \mathrm{R}_{\text {tabel }}$ maka tidak terdapat hubungan yang signifikan $\left(\mathrm{H}_{\mathrm{a}}\right)$ ditolak dan $\left(\mathrm{H}_{0}\right)$ diterima. 


\section{PEMBAHASAN}

\section{Hubungan antara Indeks Massa Tubuh terhadap Kekuatan Otot Perut Atlet Putra dan Putri}

Berdasarkan hasil tes komponen kondisi fisik kekuatan otot perut (sit up) atlet muaythai pusat pelatihan Kabupaten Malang diperoleh 6 atlet putra kategori sangat baik sebanyak 1 orang (16\%), kategori baik 0 orang $(0 \%)$, kategori cukup 1 orang (17\%), kategori kurang 3 orang $(50 \%)$, kategori sangat kurang 1 orang $(17 \%)$. Sedangkan berdasarkan hasil tes data yang telah diperoleh dari 3 atlet muaythai putri kategori sangat baik sebanyak 0 orang $(0 \%)$, kategori baik 0 orang $(0 \%)$, kategori cukup 2 orang $(67 \%)$, kategori kurang 1 orang $(33 \%)$, kategori sangat kurang 0 orang $(0 \%)$.

Berdasarkan hasil analisis korelasi atlet putra antara indeks massa tubuh terhadap kekuatan otot perut ( Sit Up), kemudian dilakukan penghitungan korelasi menggunakan rumus korelasi product moment dari Pearson dan diperoleh korelasi sebesar 0,218 . Kemudian untuk menguji signifikansi korelasi product moment dari Pearson menggunakan uji $r_{\text {hitung }}$ dibandingkan dengan $r_{\text {tabel. }}$. Lalu diperoleh $r_{\text {hitung }}$ sebesar 0,218 dengan signifikansi $a=0,05$ dan $r_{\text {tabel }}$ 0,811 Dapat disimpulkan bahwa dari perhitungan di atas tidak terdapat hubungan yang signifikan karena apabila $r_{\text {hitung }}>r_{\text {tabel }}$ terdapat hubungan yang signifikan. Sebaliknya jika $r_{\text {hitung }}<r_{\text {tabel }}$ maka tidak terdapat hubungan yang signifikan. Sedangkan analisis korelasi atlet putri dilakukan penghitungan korelasi menggunakan rumus korelasi product moment dari Pearson dan diperoleh korelasi sebesar -0,987. Kemudian untuk menguji signifikansi korelasi product moment dari Pearson menggunakan uji rhitung

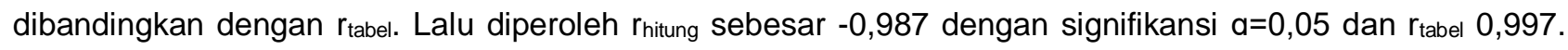
Dapat disimpulkan bahwa dari perhitungan di atas tidak terdapat hubungan yang signifikan karena apabila $r_{\text {hitung }}>r_{\text {tabel }}$ terdapat hubungan yang signifikan. Sebaliknya jika $r_{\text {hitung }}<r_{\text {tabel }}$ maka tidak terdapat hubungan yang signifikan.

Berdasarkan hasil perhitngan sumbangan efektif dan sumbangan relatif atlet putra dapat diketahui nilai $R$ square sebesar 0.015 dengan demikian variabel bebas Indeks Massa Tubuh hanya menyumbang sebesar $1,5 \%$ terhadap variabel terikat kekuatan otot perut sedangkan sisanya $98,5 \%$ dipengaruhi oleh variabel lain. Dari tabel di atas diperoleh hasil sumbangan efektif yang diberikan sebesar $1,5 \%=R$ square. Sedangkan sumbangan relatif yang diberikan $100 \%$. Sedangkan hasil perhitngan sumbangan efektif dan sumbangan relatif atlet putri dapat diketahui nilai $R$ square sebesar 0.976 dengan demikian variabel bebas Indeks Massa Tubuh hanya menyumbang sebesar $9,76 \%$ terhadap variabel terikat kekuatan otot perut sedangkan sisanya $90,24 \%$ dipengaruhi oleh variabel lain. Hasil sumbangan efektif yang diberikan sebesar $9,76 \%=R$ square. Sedangkan sumbangan relatif yang diberikan $100 \%$.

Berdasarkan teori yang dikemukakan oleh Azkia \& Miko Wahyono (2019) dan Sofa (2018) hubungan antara berat badan dan kemampuan otot perut adalah pemahaman hubungan antara kemampuan anerobik dan kemampuan aerobik mengenai hubungan antara intensitas dan durasi dalam memaksimalkan kerja organ tubuh atau kondisi fisik. Teori ini sejalan dengan penelitian ini yang menunjukkan bahwa tidak ada hubungan yang signifikan antara indeks massa tubuh dengan kekuatan otot perut.

Hasil penelitian ini juga sejalan dengan peneltian terdahulu yang menyatakan tidak ada hubungan yang signifikan antara indeks massa tubuh dengan kekuatan otot perut. Berdasarkan hasil penelitian terdahulu yang dilakukan oleh Siregar dan Sitompul (2019) tersebut bahwa dari 20 sampel yang telah diteliti menunjukkan bahwa seluruh atlet yang telah diteliti indeks massa tubuh berkategori normal dengan nilai indeks massa tubuh paling rendah adalah $18,21 \%$ dan paling tinggi adalah $25,61 \%$ dengan rata-rata $21,37 \%$ dan dari hasil tes kekuatan otot atlet SSB Tunas Muda Medan, kategori terbanyak adalah cukup dengan jumlah (12 orang) kategori baik (4 orang) kategori baik sekali (3 orang). Dengan persentase rata-rata $36,2 \%$. Dengan hasil korelasional antara Indeks massa tubuh dengan kekuatan otot perut yaitu 0,07 dengan taraf signifikansi $(>0,05)$.

\section{Hubungan antara Indeks Massa Tubuh terhadapa Kekuatan Otot Lengan}

Berdasarkan hasil tes komponen kondisi fisik kekuatan otot Irngan (push up) atlet muaythai putra kategori baik sekali sebanyak 0 orang $(0 \%)$, kategori baik 0 orang $(0 \%)$, kategori sedang 2 orang (33\%), kategori kurang 3 orang $(67 \%)$, kategori kurang sekali 0 orang $(0 \%)$. Sedangkan hasil tes push up atlet muaythai putri pusat pelatihan Kabupaten Malang diperoleh hasil prsentase yaitu, atlet muaythai putri kategori baik sekali sebanyak 0 orang $(0 \%)$, kategori baik 0 orang $(0 \%)$, kategori sedang 0 orang $(0 \%)$, kategori kurang 3 orang $(100 \%)$, kategori kurang sekali 0 orang $(0 \%)$. 
Berdasarkan hasil analisis korelasi indeks massa tubuh terhadap kekuatan otot lengan (Push Up), kemudian dilakukan penghitungan menggunakan rumus korelasi product moment dari Pearson dan diperoleh korelasi sebesar 0,395. Kemudian untuk menguji signifikansi korelasi product moment dari Pearson menggunakan uji

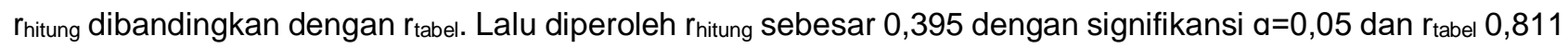
Dapat disimpulkan bahwa dari perhitungan di atas tidak terdapat hubungan yang signifikan karena apabila $r_{\text {hitung }}>r_{\text {tabel }}$ terdapat hubungan yang signifikan. Sebaliknya jika $r_{\text {hitung }}<r_{\text {tabel }}$ maka tidak terdapat hubungan yang signifikan. Sedangkan korelasi hasil analisis atlet putri kemudian dilakukan penghitungan menggunakan rumus korelasi product moment dari Pearson dan diperoleh korelasi sebesar $-0,277$. Kemudian untuk menguji signifikansi korelasi product moment dari Pearson menggunakan uji ritung dibandingkan dengan $r_{\text {tabel. }}$ Lalu

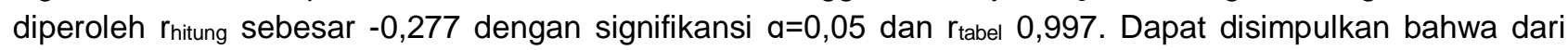
perhitungan di atas tidak terdapat hubungan yang signifikan karena apabila $r_{\text {hitung }}>r_{\text {tabel }}$ terdapat hubungan yang signifikan. Sebaliknya jika rhitung $<$ rabel maka tidak terdapat hubungan yang signifikan.

Berdasarkan hasil perhitungan sumbangan efektif dan sumbangan relatif atlet putra dapat diketahui nilai $R$ square sebesar 0.157 dengan demikian variabel bebas Indeks Massa Tubuh hanya menyumbang sebesar $15,7 \%$ terhadap variabel terikat kekuatan otot lengan sedangkan sisanya $84,3 \%$ dipengaruhi oleh variabel lain. Dari tabel di atas diperoleh hasil sumbangan efektif yang diberikan sebesar $15,7 \%=R$ square. Sedangkan sumbangan relatif yang diberikan $100 \%$. Sedangkan hasil perhitungan sumbangan efektif dan sumbangan relatif atlet putri dapat diketahui nilai $R$ square sebesar 0.077 dengan demikian variabel bebas Indeks Massa Tubuh hanya menyumbang sebesar $7,7 \%$ terhadap variabel terikat kekuatan otot lengan sedangkan sisanya $92,3 \%$ dipengaruhi oleh variabel lain. Hasil sumbangan efektif yang diberikan sebesar $7,7 \%=R$ square. Sedangkan sumbangan relatif yang diberikan $100 \%$.

Berdasarkan teori yang dikemukakan oleh Liana, Soharno, \& Panjaitan (2018) bahwa indeks massa tubuh belum tentu dapat meningkatkan kapasitas kekuatan otot, kapasitas maksimal otot maupun power pada tubuh seseorang. Teori ini sejalan dengan penelitian ini yang menunjukkan bahwa tidak ada hubungan yang signifikan antara indeks massa tubuh dengan kekuatan otot lengan.

Dari hasil penelitian Siregar dan Sitompul (2019) dengan judul hubungan indeks massa tubuh terhadap kondisi fisik atlet SBB Tunas Muda, dari 20 sampel yang telah diteliti menunjukkan bahwa seluruh atlet yang telah diteliti indeks massa tubuh berkategori normal dengan nilai indeks massa tubuh paling rendah adalah $18,21 \%$ dan paling tinggi adalah $25,61 \%$ dengan rata-rata $21,37 \%$ dan dari hasil tes kekuatan otot atlet SSB Tunas Muda Medan, kategori terbanyak adalah cukup dengan jumlah (12 orang) kategori baik (4 orang) kategori baik sekali (3 orang). Dengan persentase rata-rata 36,2\%.menyatakan bahwa tidak ada hubungan yang signifikan antara indeks massa tubuh dengan kekuatan otot lengan dengan nilaip $=0,07>0,05$. Sebagaimana yang terdapat dalam penelitian ini bahwa tidak ada hubungan yang signifikan antara indeks massa tubuh dengan kekuatan otot lengan atlet muaythai Kabupaten Malang.

\section{Hubungan antara Indeks Massa Tubuh terhadapa Kekuatan Daya Ledak}

Berdasarkan hasil tes komponen kondisi fisik daya ledak (standung long jump) atlet muaythai pusat pelatihan Kabupaten Malang diperoleh 6 atlet putra. Kategori baik sekali sebanyak 1 orang (16\%), kategori baik 0 orang $(0 \%)$, kategori cukup 1 orang $(17 \%)$, kategori sedang 1 orang (17\%), kategori kurang 2 orang $(33 \%)$, kategori poor 1 orang $(17 \%)$, kategori very poor $(0 \%)$. Sedangkan hasil tes standing long jump atlet muaythai pusat pelatihan Kabupaten Malang diperoleh 3 atlet putri. Kategori baik sekali sebanyak 0 orang $(0 \%)$, kategori baik 1 orang $(33 \%)$, kategori cukup 0 orang $(0 \%)$, kategori sedang 1 orang $(34 \%)$, kategori kurang 1 orang $(33 \%)$, kategori poor 0 orang $(0 \%)$, kategori very poor $(0 \%)$.

Berdasarkan hasil analisis atlet putra antara indeks massa tubuh dengan daya ledak, kemudian dilakukan perhitungan korelasi menggunakan rumus korelasi product moment dari Pearson dan diperoleh korelasi sebesar 0,836. Kemudian untuk menguji signifikansi korelasi product moment dari Pearson menggunakan uji $r_{\text {hitung }}$ dibandingkan dengan $r_{\text {tabel. }}$. Lalu diperoleh $r_{\text {hitung }}$ sebesar 0,836 dengan signifikansi $a=0,05$ dan $r_{\text {tabel }} 0,811$ Dapat disimpulkan bahwa dari perhitungan di atas terdapat hubungan yang signifikan karena apabila $r_{\text {hitung }}>$ $r_{\text {tabel }}$ terdapat hubungan yang signifikan. Sebaliknya jika $r_{\text {hitung }}<$ rtabel maka terdapat hubungan yang signifikan. Sedangkan hasil analisis atlet putri antara indeks massa tubuh dengan daya ledak dilakukan penghitungan korelasi menggunakan rumus korelasi product moment dari Pearson dan diperoleh korelasi sebesar 0,999. Kemudian untuk menguji signifikansi korelasi product moment dari Pearson menggunakan uji rhitung dibandingkan dengan $r_{\text {tabel. }}$. Lalu diperoleh $r_{\text {hitung }}$ sebesar 0,999 dengan signifikansi a=0,05 dan $r_{\text {tabel }}$ 0,997. 
Dapat disimpulkan bahwa dari perhitungan di atas terdapat hubungan yang signifikan karena apabila rhitung $>$ $r_{\text {tabel }}$ terdapat hubungan yang signifikan. Sebaliknya jika $r_{\text {hitung }}<r_{\text {tabel }}$ maka terdapat hubungan yang signifikan.

Berdasarkan hasil perhitungan sumbangan efektif dan sumbangan relatif atlet putra dapat diketahui nilai $R$ square sebesar 0.720 dengan demikian variabel bebas Indeks Massa Tubuh menyumbang sebesar $72 \%$ terhadap variabel terikat daya ledak sedangkan sisanya $28 \%$ dipengaruhi oleh variabel lain. Dari tabel di atas diperoleh hasil sumbangan efektif yang diberikan sebesar $72 \%=R$ square. Sedangkan sumbangan relatif yang diberikan $100 \%$. Sedangan hasil perhitungan sumbangan efektif dan sumbangan relatif atlet putri dapat diketahui nilai $R$ square sebesar 0,999 dengan demikian variabel bebas indeks massa tubuh hanya menyumbang sebesar $99,9 \%$ terhadap variabel terikat daya ledak sedangkan sisanya $0,1 \%$ dipengaruhi oleh variabel lain. Hasil sumbangan efektif yang diberikan sebesar $99,9 \%=R$ square. Sedangkan sumbangan relatif yang diberikan $100 \%$.

Berdasarkan teori yang dikemukakan oleh Hutahaean, Tarigan, \& Ardinata (2018) bahwa daya ledak merupakan kemampuan untuk mengerahkan kekuatan maksimal dalam waktu yang cepat. Tentu dalam melalukan daya ledak membutuhkan indeks massa tubuh yang bagus supaya gerakan yang cepat dan maksimal dapat dilakukan. Teori ini sejalan dengan penelitian ini yang menunjukkan ada hubungan yang signifikan antara indeks massa tubuh dengan daya ledak.

Dari hasil penelitian Girsang, Munthe, \& Pribadi (2019) dengan judul Hubungan Indeks Massa Tubuh dan Kekuatan Otot Tungkai dengan Keseimbangan Tubuh pada SSB Lowo ljo Kabupaten Grobogan. Menyatakan bahwa ada hubungan yang signifikan antara indeks massa tubuh dengan daya ledak atau kekuatan otot tungkai pada atlet muaythai Kabupaten Malang dengan menggunakan tes komponen kondisi fisik long jump. Dari penelitian terdahulu dan analisis data yang sudah dilakukan bahwa ada kesamaan bahwa ada hubungan antara indeks massa tubuh dengan daya ladak (long jump) atau kekuatan otot tungkai.

Berbekal teori dari Adityatama (2017) mengemukakan bahwa kekuatan otot tungkai adalah komponen seseorang tentang kemampuannya dalam mempergunakan otot tungkai menerima beban sewaktu melakukan aktifitas fisik. Dalam menjaga aktifitas fisik perlu adanya perhatian khusus tentang asupan makanan yang dikonsumsi seseorang atau atlet. Asupan makanan yang dikonsumsi akan berpengaruh terhadap bentuk dan kekuatan otot dalam memaksimalkan fungsi anggota tubuh. Maka dari itu berbekal teori, penelitian terdahulu serta analisis data yang sudah dilakukan bahwa ada hubungan yang signifikan antara kondisi fisik antara indeks massa tubuh dengan daya ledak atlet muaythai Kabupaten Malang, dengan menjaga asupan makan dan menjalankan program latihan dengan baik akan sangat berpengaruh terhadap kondisi fisik khususnya daya ledak atlet.

\section{Hubungan antara Indeks Massa Tubuh terhadapa Kecepatan}

Berdasarkan hasil tes komponen kondisi fisik kecepatan (sprint) atlet muaythai pusat pelatihan Kabupaten Malang diperoleh 6 atlet putra. Kategori atlet muaythai putra kategori unggul sebanyak 2 orang (33\%), di atas rata-rata 2 orang (33\%), rata-rata 2 orang $(34 \%)$, kategori di bawah rata-rata 0 orang $(0 \%)$, kategori kurang 0 orang $(0 \%)$. Sedangkan hasil tes kecepatan data yang telah diperoleh atlet muaythai putri pusat pelatihan Kabupaten Malang berdasarkan diperoleh hasil presentase yaitu, kategori atlet muaythai putri kategori unggul sebanyak 0 orang $(0 \%)$, di atas rata-rata 0 orang $(0 \%)$, rata-rata 0 orang $(0 \%)$, kategori di bawah rata-rata 2 orang $(67 \%)$, kategori kurang 1 orang $(33 \%)$.

Berdasarkan hasil analisis korelasi atlet putra antara indeks massa tubuh terhadap kecepatan (sprint) kemudian dilakukan penghitungan korelasi menggunakan rumus korelasi product moment dari Pearson dan diperoleh korelasi sebesar 0,363. Kemudian untuk menguji signifikansi korelasi product moment dari Pearson menggunakan uji $r_{\text {hitung }}$ dibandingkan dengan $r_{\text {tabel. }}$. Lalu diperoleh $r_{\text {hitung }}$ sebesar 0,363 dengan signifikansi $a=0,05$ dan $r_{\text {tabel }}$ 0,811 Dapat disimpulkan bahwa dari perhitungan di atas tidak terdapat hubungan yang signifikan karena apabila $r_{\text {hitung }}>r_{\text {tabel }}$ terdapat hubungan yang signifikan. Sebaliknya jika $r_{\text {hitung }}<r_{\text {tabel }}$ maka tidak terdapat hubungan yang signifikan. Berdasarkan hasil analisis korelasi atlet putri antara indeks massa tubuh terhadap kecepatan (sprint), kemudian dilakukan penghitungan korelasi menggunakan rumus korelasi product moment dari Pearson dan diperoleh korelasi sebesar 0,438. Kemudian untuk menguji signifikansi korelasi product moment dari Pearson menggunakan uji rhitung dibandingkan dengan $\mathrm{r}_{\text {tabel. }}$. Lalu diperoleh rhitung sebesar 0,438 dengan signifikansi $a=0,05$ dan $r_{\text {tabel }}$ 0,997. Dapat disimpulkan bahwa dari perhitungan di atas tidak terdapat hubungan yang signifikan karena apabila $r_{\text {hitung }}>r_{\text {tabel }}$ terdapat hubungan yang signifikan. Sebaliknya jika $r_{\text {hitung }}<$ rtabel maka tidak terdapat hubungan yang signifikan. 
Berdasarkan hasil perhitungan sumbangan efektif dan sumbangan relatif atlet putra dapat diketahui nilai $R$ square sebesar 0,138 dengan demikian variabel bebas Indeks Massa Tubuh hanya menyumbang sebesar $13,8 \%$ terhadap variabel terikat kecepatan sedangkan sisanya $86,2 \%$ dipengaruhi oleh variabel lain. Dari tabel di atas diperoleh hasil sumbangan efektif yang diberikan sebesar $13,8 \%=R$ square. Sedangkan sumbangan relatif yang diberikan $100 \%$. Sedangkan hasil perhitungan sumbangan efektif dan sumbangan relatif atlet putri dapat diketahui nilai $R$ square sebesar 0,193 dengan demikian variabel bebas Indeks Massa Tubuh hanya menyumbang sebesar $19,3 \%$ terhadap variabel terikat kecepatan sedangkan sisanya $80,7 \%$ dipengaruhi oleh variabel lain. Hasil sumbangan efektif yang diberikan sebesar $19,3 \%=R$ square. Sedangkan sumbangan relatif yang diberikan $100 \%$.

Berdasarkan teori yang dikemukakan oleh Mustika, Hidayati L, Kusumawati, \& Lusiana (2019) menyatakan bahwa indeks massa tubuh merupakan faktor yang mempengaruhi kondisi fisik ataupun mempengaruhi kecepatan atlet. Karena indeks massa tubuh yang ideal tentu akan mempermudah gerak atau mempermudah atlet untuk berlari ataupun bergerak lebih cepat.

Teori tersebut bertolak belakang dengan hasil penelitian ini karena dari hasil analisis data menunjukkan bahwa tidak ada hubungan yang signifikan antara indeks massa tubuh dengan kecepatan. Dari penelitian ini juga menunjukkan bahwa indeks massa tubuh hanya menyumbang sebesar $13,8 \%$ terhadap kecepatan.

Dari penelitian terdahulu dan analisi data yang sudah dilakukan sejalan dengan teori Puspitasari (2019) kondisi fisik yang baik akan berpengaruh terhadap fungsi dan sistem organisasi tubuh diantaranya, akan ada peningkatan dalam kemampuan sistem sirkulasi dan kerja jantung, akan ada pemulihan yang lebih cepat dalam organisme tubuh apabila sektu-waktu respon diperlukan, khususnya komponen kondisi fisik kecepatan. Faktor yang mempengaruhi indeks massa tubuh atlet tersebut menjadi baik yaitu perolehan atau tubuh memperoleh cukup asupan makanan yang seimbang yang digunakan secara efisien sehingga memungkinkan pertumbuhan fisik, pertumbuhuan otak, kemampuan kerja dan kesehatan tubuh secara optimal (Istiany, 2013:5).

\section{Hubungan antara Indeks Massa Tubuh terhadap Daya Tahan}

Berdasarkan hasil tes komponen kondisi fisik daya tahan (MFT) atlet muaythai pusat pelatihan Kabupaten Malang diperoleh 6 atlet putra. Kategori sangat baik sebanyak 0 orang $(0 \%)$, baik $2(33 \%)$, di atas rata-rata $(0 \%)$, rata-rata 4 orang $(67 \%)$, Di bawah rata-rata 0 orang $(0 \%)$, jelek 0 orang $(0 \%)$. Sedangkan hasil tes komponen kondisi fisik daya tahan (MFT) atlet muaythai pusat pelatihan Kabupaten Malang diperoleh 3 atlet putri. Kategori atlet muaythai putri kategori sangat baik sebanyak 0 orang $(0 \%)$, baik $0(0 \%)$, di atas rata-rata $(0 \%)$, rata-rata orang $(0 \%)$, Di bawah rata-rata 3 orang $(100 \%)$, jelek 0 orang $(0 \%)$.

Berdasarkan hasil analisis korelasi atlet putra antara indeks massa tubuh terhadap daya tahan (MFT) kemudian dilakukan penghitungan korelasi menggunakan rumus korelasi product moment dari Pearson dan diperoleh korelasi sebesar 0,234. Kemudian untuk menguji signifikansi korelasi product moment dari Pearson

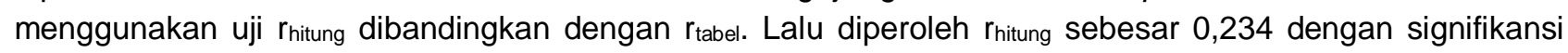
$a=0,05$ dan $r_{\text {tabel }}$ 0,811 Dapat disimpulkan bahwa dari perhitungan di atas tidak terdapat hubungan yang signifikan karena apabila $r_{h i t u n g}>r_{\text {tabel }}$ terdapat hubungan yang signifikan. Sebaliknya jika $r_{\text {hitung }}<r_{\text {tabel }}$ maka tidak terdapat hubungan yang signifikan. Berdasarkan hasil analisis korelasi atlet putri antara indeks massa tubuh terhadap daya tahan (MFT), kemudian dilakukan penghitungan korelasi menggunakan rumus korelasi product moment dari Pearson dan diperoleh korelasi sebesar 0,327. Kemudian untuk menguji signifikansi korelasi product moment dari Pearson menggunakan uji rhitung dibandingkan dengan $r_{\text {tabel. }}$ Lalu diperoleh $\mathrm{r}_{\text {hitung }}$ sebesar 0,327 dengan signifikansi $a=0,05$ dan $r_{\text {tabel }}$ 0,997. Dapat disimpulkan bahwa dari perhitungan di atas tidak terdapat hubungan yang signifikan karena apabila $r_{\text {hitung }}>r_{\text {tabel }}$ terdapat hubungan yang signifikan. Sebaliknya jika $r_{\text {hitung }}<r_{\text {tabel }}$ maka tidak terdapat hubungan yang signifikan.

Berdasarkan hasil perhitungan sumbangan efektif dan sumbangan relatif atlet putra dapat diketahui nilai $R$ square sebesar 0,056 dengan demikian variabel bebas Indeks Massa Tubuh hanya menyumbang sebesar $5,6 \%$ terhadap variabel terikat daya tahan sedangkan sisanya $94,4 \%$ dipengaruhi oleh variabel lain. Dari tabel di atas diperoleh hasil sumbangan efektif yang diberikan sebesar $5,6 \%=R$ square. Sedangkan sumbangan relatif yang diberikan $100 \%$. Berdasarkan hasil perhitungan sumbangan efektif dan sumbangan relatif atlet putri dapat diketahui nilai $R$ square sebesar 0,107 dengan demikian variabel bebas Indeks Massa Tubuh hanya menyumbang sebesar $10,7 \%$ terhadap variabel terikat daya tahan sedangkan sisanya $89,3 \%$ dipengaruhi oleh variabel lain. Hasil sumbangan efektif yang diberikan sebesar $10,7 \%=R$ square. Sedangkan 
sumbangan relatif yang diberikan $100 \%$.

Penelitian terdahulu yang dilakukan oleh Siregar dan Sitompul (2019) tersebut bahwa dari 20 sampel yang telah diteliti menunjukkan bahwa seluruh atlet yang telah diteliti indeks massa tubuh berkategori normal dengan nilai indeks massa tubuh paling rendah adalah $18,21 \%$ dan paling tinggi adalah $25,61 \%$ dengan ratarata $21,37 \%$ dan hasil tes daya tahan dari 20 atlet Atlet ssb tunas muda medan, kategori terbanyak adalah kurang sekali dengan jumlah (16 orang) kategori kurang (4 orang). Dengan persentase rata-rata 42,88 \%. Dengan hasil korelasional antara Indeks massa tubuh dengan kekuatan otot perut yaitu 0,30 dengan taraf signifikansi $(>0,05)$. Dari hasil penelitian di atas dapat disimpulkan adanya kesamaan antara teori dan peneltian terdahulu bahwa tidak ada hubungan yang signifikan antara indeks massa tubuh dengan daya tahan (MFT) pada atlet muaythai Kabupaten Malang. Karena ada sumbangan di luar indeks massa tubuh yang mempengaruhi kondisi fisik.

\section{KESIMPULAN}

Berdasarkan hasil penelitian yang sudah diuji terhadap variabel bebas indeks massa tubuh $(X)$ dengan variabel terikat kondisi fisik (Y) pada atlet muaythai Kabupaten Malang dan diperoleh hipotesis dapat dismpulkan. Indeks massa tubuh atlet muaythai Kabupaten Malang putra maupun putri tergolong normal. Hanya ada hubungan yang signifikan antara indeks massa tubuh terhadap daya ledak, tidak ada hubungan yang signifikan antara indeks massa tubuh terhadap kekuatan otot perut, otot lengan, kecepatan dan daya tahan.

\section{Ucapan Terima Kasih}

Peneliti menyadari, bahwa dalam penulisan skripsi ini tidak akan selesai tanpa bantuan dari berbagai pihak. Sehingga dikesempatan yang baik ini peneliti mengucapkan terimakasih yang sebesar-besarya kepada Dr. Sapto Adi, M.Kes., selaku Dekan Fakultas IImu Keolahragaan Universitas Negeri Malang, yang telah memberikan kesempatan bagi peneliti untuk menyelesaikan pendidikan dan menempuh jenjang sarjana di FIK UM, Dr. dr. Moch. Yunus, M.Kes., sebagai Wakil Dekan I Fakultas IImu Keolahragaan yang telah membantu dan memberikan izin dalam proses penelitian, Dr. Lokananta Teguh Hari Wiguno, M.Kes., selaku Ketua Jurusan Pendidikan Jasmani dan Kesehatan Fakultas IImu Keolahragaan, Dr. Eko Hariyanto, M.Pd., selaku Dosen Pembimbing I yang telah meluangkan waktu memberikan bimbingan, memberikan motivasi, masukan, dan saran-saran yang sangat berharga bagi peneliti, Bapak jumadi selaku pelatih dari atlet muaythai Kabupaten Malang yang telah memberikan izin mengadakan penelitian dan atlet muaythaikabupaten malang yang bersedia untuk diteliti.

\section{DAFTAR PUSTAKA}

Adityatama, F. (2017). Hubungan Power Otot Tungkai, Koordinasi Mata Kaki Dan Kekuatan Otot Perut Dengan Ketepatan Menembak Bola. JUARA : Jurnal Olahraga. https://doi.org/10.33222/juara.v2i2.37

Ariffiansyah, G. (2019). Peningkatan Kemampuan Kelincahan Gerak Akibat Latihan Kelincahan T-Drill Maju dan T-Drill Mundur Terhadap Kelincahan Gerak Olahragawan Karate Dojo Cakrawala Kota Malang. Sport Science and Health, 1(3), 227-232. Retrieved from http://journal2.um.ac.id/index.php/ffik/index

Arifin, R., \& Warni, H. (2019). Model Latihan Kelincahan Sepakbola. Multilateral Jurnal Pendidikan Jasmani Dan Olahraga. https://doi.org/10.20527/multilateral.v17i2.5702

Azkia, F. I., \& Miko Wahyono, T. Y. (2019). Hubungan Pola Konsumsi Makanan Berisiko dengan Obesitas Sentral Pada Wanita Usia 25-65 Tahun di Bogor Tahun 2011-2012. Jurnal Epidemiologi Kesehatan Indonesia. https://doi.org/10.7454/epidkes.v2i1.1675

Bohlen, A., Boll, M., Schwarzer, M., \& Groneberg, D. A. (2015). Body-Mass-Index. Diabetologe. https://doi.org/10.1007/s11428-015-1388-8

Chinnasee, C., Mohamad, N. I., Nadzalan, A. M., Sazili, A. H. A., Hemapandha, W., Pimjan, L., ... Tan, K. (2018). Lower limb kinematics analysis during roundhouse kick among novices in muay thai. Journal of 
Fundamental and Applied Sciences. https://doi.org/10.4314/jfas.v9i6s.73

Chinnasee, Chamnan, Nadzalan, A. M., Mohamad, N. I., Ahmad Sazili, A. H., Hemapandha, W., Azizuddin Khan, T. K., ... Tan, K. (2018). Kinematics Analysis of Dominant and Non-Dominant Lower Limb during Knee Strike among MuayThai Beginners. Journal of Physics: Conference Series. https://doi.org/10.1088/1742-6596/1020/1/012006

Diniz, R., Del Vecchio, F. B., Schaun, G. Z., Oliveira, H. B., Portella, E. G., da Silva, E. S., ... Pinto, S. S. (2018). Kinematic Comparison of the Roundhouse Kick Between Taekwondo, Karate, and Muaythai. Journal of Strength and Conditioning Research. https://doi.org/10.1519/jsc.0000000000002657

Diputra, R. (2015). Pengaruh Latihan Three Cone Drill, Four Cone Drill, Dan Five Cone Drill Terhadap Kelincahan (Agility) Dan Kecepatan (Speed). Jurnal SPORTIF: Jurnal Penelitian Pembelajaran. https://doi.org/10.29407/js_unpgri.v1i1.574

Girsang, V. I., Munthe, R., \& Pribadi, T. (2019). Pengaruh Kejadian Kecacingan Terhadap Kadar Hb Dan Indeks Masa Tubuh Anak. Holistik Jurnal Kesehatan. https://doi.org/10.33024/hjk.v12i4.39

Griwijoyo, S. (2013). Ilmu Faal Olahraga. Bandung: PT Remaja Rosdakarya.

Haro, C., Rangel-Zúñiga, O. A., Alcalá-Díaz, J. F., Gómez-Delgado, F., Pérez-Martínez, P., Delgado-Lista, J., ... Camargo, A. (2016). Intestinal microbiota is influenced by gender and body mass index. PLOS ONE. https://doi.org/10.1371/journal.pone.0154090

Hartmann, H., Wirth, K., Keiner, M., Mickel, C., Sander, A., \& Szilvas, E. (2015). Short-term Periodization Models: Effects on Strength and Speed-strength Performance. Sports Medicine. https://doi.org/10.1007/s40279-015-0355-2

Haugen, T. A., Tønnessen, E., Hisdal, J., \& Seiler, S. (2014). The role and development of sprinting speed in soccer. International Journal of Sports Physiology and Performance. https://doi.org/10.1123/lJSPP.2013-0121

Horicka, P., Hianik, J., \& Šimonek, J. (2014). The relationship between speed factors and agility in sport games. Journal of Human Sport and Exercise. https://doi.org/10.4100/jhse.2014.91.06

Hutahaean, M. E. R., Tarigan, A. P. S., \& Ardinata, D.-. (2018). Hubungan Polimorfisme Gen ACTN-3 (R577X) dengan Daya Ledak Otot pada Siswa Sekolah Sepakbola di Medan. Jurnal Kedokteran Brawijaya. https://doi.org/10.21776/ub.jkb.2018.030.02.8

Istiany, A. \& R. (2013). Gizi Terapan. Bandung: PT Remaja Rosdakarya.

Labocha, M. K., Schutz, H., \& Hayes, J. P. (2014). Which body condition index is best? Oikos. https://doi.org/10.1111/j.1600-0706.2013.00755.x

Liana, A. E., Soharno, S., \& Panjaitan, A. A. (2018). Hubungan Antara Pengetahuan Tentang Gizi Seimbang Dengan Indek Masa Tubuh Pada Mahasiswa. Jurnal Kebidanan. https://doi.org/10.33486/jk.v7i2.10

Locke, A. E., Kahali, B., Berndt, S. I., Justice, A. E., Pers, T. H., Day, F. R., ... Econs, M. J. (2015). Genetic studies of body mass index yield new insights for obesity biology. Nature. https://doi.org/10.1038/nature14177

Mach, N., \& Fuster-Botella, D. (2017). Endurance exercise and gut microbiota: A review. Journal of Sport and Health Science. https://doi.org/10.1016/j.jshs.2016.05.001

Montoya, S. (2019). Las percepciones de la frustracion en un grupo de deportistas de alto rendimiento de Muay Thai en Medellin. Revista de Artes Marciales.

Mustika, I., Hidayati L, S., Kusumawati, E., \& Lusiana, N. (2019). Anemia Defisiensi Besi Dan Indeks Massa Tubuh Terhadap Siklus Menstruasi Remaja Putri. Jurnal Kesehatan. https://doi.org/10.24252/kesehatan.v12i1.7157

Nuttall, F. Q. (2015). Body mass index: Obesity, BMI, and health: A critical review. Nutrition Today. https://doi.org/10.1097/NT.0000000000000092

Orhan, S., Yücel, A., Sadeq, B., \& Orhan, E. (2019). Investigation of the Exercise Dependence of Athletes 
Doing Kickboxing, Taekwondo and Muaythai. Sports. https://doi.org/10.20944/preprints201901.0233.v1

Phosawat Saengsawang, Chairit Siladech, \& Prapat Laxanaphisuth. (2015). The History and Development of Muaythai Boran. Journal of Sports Science. https://doi.org/10.17265/2332-7839/2015.03.007

Prihatini, Dwi A \& Widodo Achmad. 2019. Hubungan Antara Indeks Massa Tubuh Dengan Daya Tahan Kardiovaskuler dan Kelincahan Pemain Sepakbola. Surabaya. Universitas Negeri Surabaya.

Puspitasari, N. (2019). Faktor Kondisi Fisik Terhadap Resiko Cedera Olahraga Pada Permainan Sepakbola. Jurnal Fisioterapi Dan Rehabilitasi. https://doi.org/10.33660/jfrwhs.v3i1.34

Queensland Goverment. (2013). Using Body Mass Index. Nutrition Education Materials Online.

Rahmansyah, B., Jufrianis, J., \& Tangkudung, J. (2018). The Effects Of Explosive Limb Muscle Strength, EyeFoot Coordination And Self-Confidence In Shooting Skills. JIPES - Journal Of Indonesian Physical Education And Sport. https://doi.org/10.21009/jipes.042.09

Samsudin, S., \& Rahman, H. A. (2016). Pengaruh metode pembelajaran drill, bermain, dan kelincahan terhadap kemampuan passing dalam permainan bola voli. Jurnal Keolahragaan. https://doi.org/10.21831/jk.v4i2.10899

Setiawan, Irwan.(2014). Profil Kondisi Fisik Atlet Tarung Derajat Pusat Pelatihan Kota Kediri Dalam Menghadapi Kejuaraan Provinsi Jawa Timur Tahun 2017. 2(3), 89-97.

Siregar, N. S., \& Sitompul, S. F. M. (2019). Hubungan Status Gizi Terhadap Kondisi Fisik Atlet SSB Tunas Muda. 3(1), 47-55.

Sofa, I. M. (2018). Kejadian Obesitas, Obesitas Sentral , dan Kelebihan Lemak Viseral pada Lansia Wanita The Incidence of Obesity , Central Obesity , and Excessive Visceral Fat among Elderly Women. Amerta Nutr. https://doi.org/10.20473/amnt.v2.i3.2018.228-236

Suchomel, T. J., Nimphius, S., Bellon, C. R., \& Stone, M. H. (2018). The Importance of Muscular Strength: Training Considerations. Sports Medicine. https://doi.org/10.1007/s40279-018-0862-z

Suchomel, T. J., Nimphius, S., \& Stone, M. H. (2016). The Importance of Muscular Strength in Athletic Performance. Sports Medicine. https://doi.org/10.1007/s40279-016-0486-0

Sunardi, D. rahmawati, Sujiono, B., \& Marani, I. N. (2019). Hubungan Antara Panjang Tungkai Dan Daya Ledak Otot Tungkai Terhadap Hasil Lari 100 Meter Atlet Atletik. Jurnal IImiah Sport Coaching and Education. https://doi.org/10.21009/jsce.03213

Volek, J. S., Noakes, T., \& Phinney, S. D. (2015). Rethinking fat as a fuel for endurance exercise. European Journal of Sport Science. https://doi.org/10.1080/17461391.2014.959564

Yuliana, \& Winarno, M. E. (2020). Hubungan Aktivitas Fisik dan Pola Makan Terhadap Status Obesitas Pada Siswa Sekolah Menengah Pertama. Sport Science and Health, 2(6), 301-311. Retrieved from http://journal2.um.ac.id/index.php/fik/article/view/11729 